\title{
Libraries in Soviet architecture of the late 1920s-1930s
}

\author{
Irina Cheredinaํㅜ, Ekaterina Rybakova²
}

\begin{abstract}
:
The article is devoted to the design and construction of libraries in the USSR as one of the most important types of public buildings in the late 1920s-1930s. Trends in space-planning techniques for the development of libraries, functional content and architectural solutions are identified. The competition for the Lenin Library in Moscow in 1928 and the influence of the architectural preferences of the time on the submitted projects are considered.
\end{abstract}

\section{KEYWORDS:}

competitive projects of the VKHUTEMAS library; competition for the V.I. Lenin State Library of the USSR; architectural preferences; specifics of library design

\section{Introduction}

The revolution of 1917 drew a sharp line between the old and the new world. The abolition of private ownership of land, the birth of ideas for the design of a working home, the search for the organization of a new way of life, contributed to the development of completely different methods of creative thinking and their implementation in architecture.

As a result of social changes, the cultural revolution of the 1920s was reflected primarily in public buildings: clubs, schools, and libraries. In connection with the approval of the All-Russian Emergency Commission for the Elimination of Illiteracy and the decree of the same name issued in 1923, literacy schools, workers' clubs and libraries were created everywhere.

The nature of the architect's work also changed: instead of fulfilling individual orders, the architect became a creator, setting and improving architectural standards, organizing cities and experimenting with new types of structures for a new person. This approach to architectural creativity was based on the method of functional design. During this period, the value of architects who were able to take a fresh look at the formation and style in a rapidly changing social world increased. The leading figure of architectural rationalism was $\mathrm{N}$. Ladovsky, whose leading workshop at the Faculty of Architecture of VKHUTEMAS was distinguished by the richness of ideas and formal searches. It was N. Ladovsky who, as the first project assignment for senior students, proposed the project of the library building - a structure that was to become one of the most significant, and at the same time, accessible to the city social and cultural centers.

\section{Search for new forms. Diploma projects of constructivist architects}

The first steps towards the creation of innovative architecture were taken by an initiative group of undergraduate students led by S. Mochalov, V. Balikhin and N. Krasilnikov, who opposed

${ }^{1}$ Moscow Architectural Institute (State Academy), Chair Soviet and modern foreign architecture, Russia, 107031, Moscow St. Rozhdestvenka 11/4, housing 1, building 4, e-mail: cherrina@mail.ru, orcid id: 0000-0002-3662-6035

2 Moscow Architectural Institute (State Academy), Chair Soviet and modern foreign architecture, Russia, 107031, Moscow,

St. Rozhdestvenka 11/4, housing 1, building 4, e-mail: rbkv.ey@gmail.com, orcid id: 0000-0003-4350-6637 
the classics and the individual method of teaching offered to their students by I. Zholtovsky, A. Shchusev, and I. Rylsky. The rebel students, inspired by the ideas of N. Ladovsky about the role of space in architecture, initiated the organization of OBMAS (united workshops). The role of OBMAS, which lasted only three years, was very large-scale: under the leadership of $\mathrm{N}$. Ladovsky's teaching method was introduced, which influenced a new approach to the creation of architectural forms.

The first pre-graduate library projects made by senior students of OBMAS (V. Balikhin, S. Mochalov, N. Krasilnikov) had a three-dimensional expressiveness and had complex volumes resembling sea shells, but rather simple plans in their content (Fig. 1).
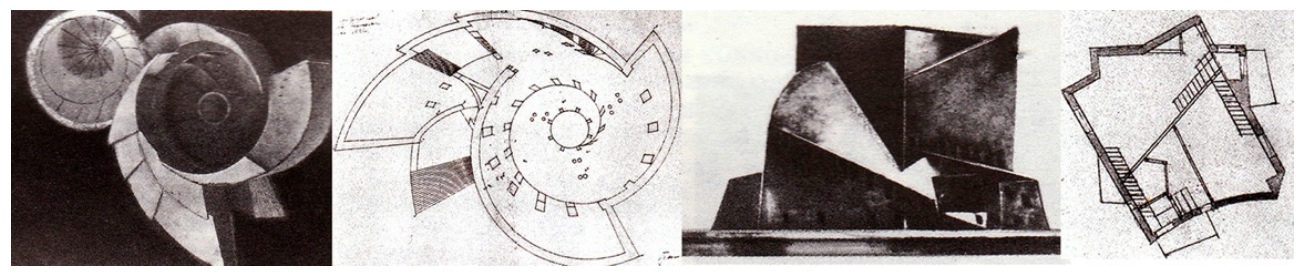

Fig. 1. Pre-graduate projects of V. Balikhin and S. Mochalov. Obmas Vkhutemasa. 1921. Plans; layouts

In the following years, VKhUTEMAS continued to experiment with the projects of urban libraries and rural reading rooms. This topic had been popular for a long time, which means it is possible see certain changes in the solution of the architectural image of the library in different years. Teachers and students continued to develop a new type of city library: the volume became more complex, and the library gradually turned from a detached building into a large complex that included cultural, educational and scientific functions.

Thus was created the famous project of A. Lavinsky «cottage-reading room», exhibited at the International Exhibition of Modern Decorative and Industrial Arts in Paris in 1925

The well-known diploma project "V.I. Lenin Institute of Library Science", created by I. Leonidov, became the personification of the achievements of the Architectural faculty of VKhUTEMAS (Fig. 2). The complex created by I. Leonidov included: a library with 5 reading rooms, the Institute of Library Science, a scientific theater (planetarium) and research institutes for isolated scientific work [5, p. 120]. The project was based on the spatial interaction of geometric volumes, which demonstrated a departure from the traditional solutions of the building and led to a reorganization of the idea of the square and the city where the institute could be built. Such an extraordinary and bold project denied all canons and embodied the ideas of the constructivist method - «work today for tomorrow».
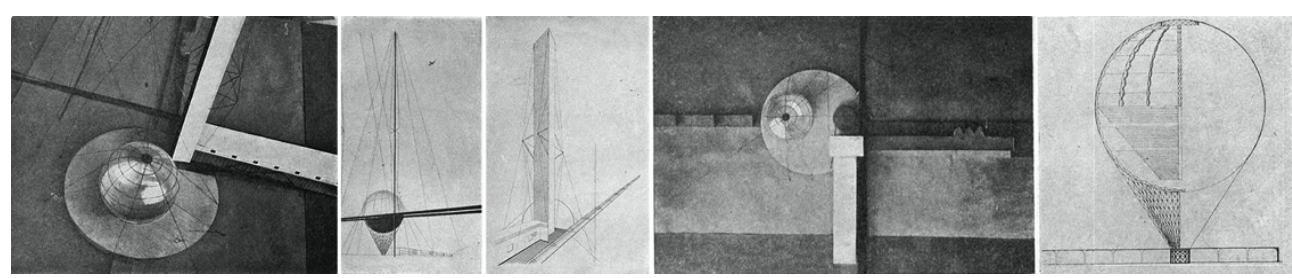

Fig. 2. Diploma project «V. I. Lenin Institute of Library Science», created by I. Leonidov

\section{Competition for the library named after V. I. Lenin}

A significant event in the architectural life of Moscow was announced in December 1927 by the Board of the State Library named after the V.I. Lenin competition for a new building. In addition to the representatives of the Library Board, the jury included high-ranking members of the government. This composition of the jury has become a tradition in subsequent competitions, including the competition for the Palace of Soviets. 
The program of the competition provided for the compliance of the building with the "character of the era», the organization of simple monumental facades, a minimum of decorative elements, but in general «the buildings should produce a harmonious and joyful impression». The conditions specified the main groups of rooms: library with book storage, card storage, lobby, lobby and service rooms; general and special reading rooms; magazine and newspaper halls; youth hall; Oriental book hall; pharmacy; post office; switchboard room; disinfection room. A storage room for books, etc.; library management rooms; an office; an institute of library science; services and workshops, as well as housing with a laundry and drying room [6, p. 3]. As a result, it was supposed to be a complex multifunctional complex, which would combine such different parts for their intended 14 projects which were submitted for the competition, 4 of which were commissioned by well-known architects and were submitted out of competition. These were the projects of A. Shchusev, the Vesnin brothers, V. Shchuko and I. Rerberg.

In the first round of the competition in 1928, the project of the young architects D. Markov, D. Fridman and V. Fidman won. The project was based on naive symbolism, where the building of the book depository depicted an open book (Fig. 3).
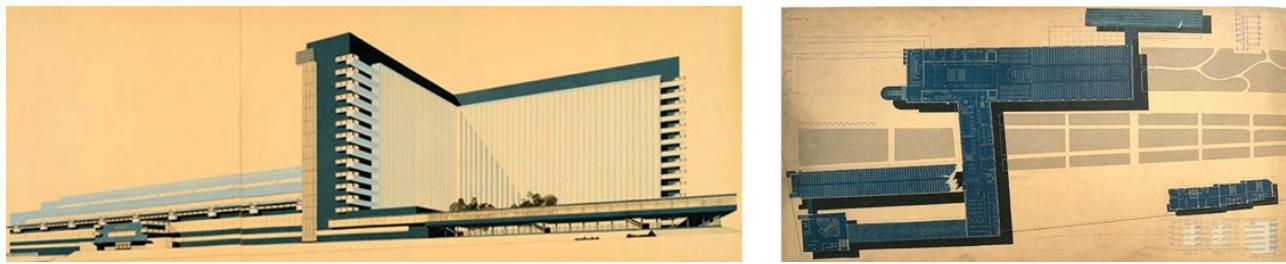

Fig. 3. D. Markov, D. Fridman and V. Fidman, Vladimir Lenin Library, competition of 1928, perspective and plans

The project of I. Rerberg was immediately criticized, since his interpretation of the library completely lacked the features of modernity. His library was too heavy and eclectic, rather like a pre-revolutionary building of the mid-nineteenth century, when the combination of different styles in one structure was almost the norm. The same features possessed the first project of A. Shchusev, which he later decisively modernized (Fig. 4).

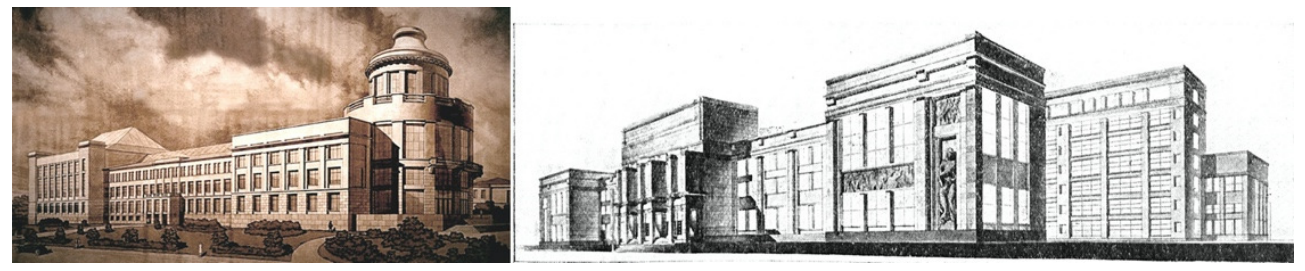

Fig. 4. I. Rerberg and A. Shchusev projects

If you turn to the projects of famous artists who were invited to demonstrate their vision of the architectural solution of the library, you can understand what trends dominated in the late 1920s.

The Vesnin brothers presented a project they had made using the constructive design method. Each function of the complex (the library was understood as a developed cultural and educational center with a large number of different functions) was provided with a separate volume. These volumes were connected to each other, based on the need for internal connections of the premises with each other. Published in the «SA» magazine in 1928, the Vesnins' project is still perceived today as a modern and beautiful solution based on a combination of glass and concrete, volumes of various shapes and sizes, and at the same time a rational distribution of the necessary functions of the building [2, p. 89] (Fig. 5).

It is obvious that the project presented by the Vesnins could be implemented these days and at the same time be an ornament of the city. 


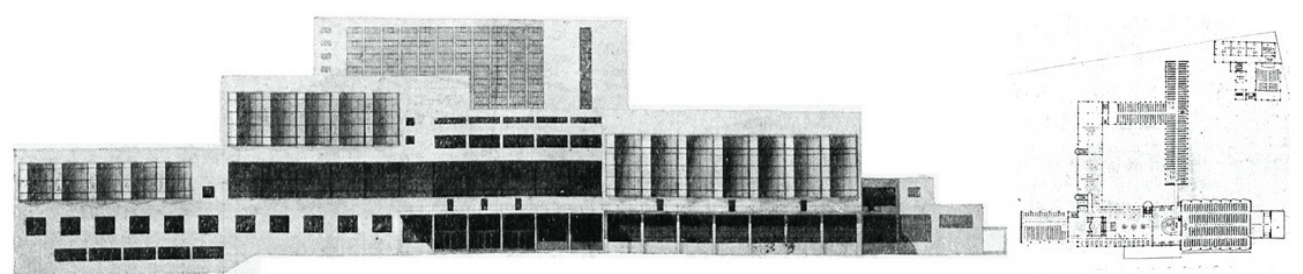

Fig. 5. L., V. and A. Vesnin, Vladimir Lenin Library, competition of 1928, facade and plans

Unlike the Vesnins, A. Shchusev proposed a composition of the library complex based on a traditional symmetrical solution and a modern appearance. The image created by the master is based on the use of tape glazing in combination with blind concrete planes. The reception emphasized the modernity of the architecture and at the same time compositionally presented the tradition (Fig. 6).
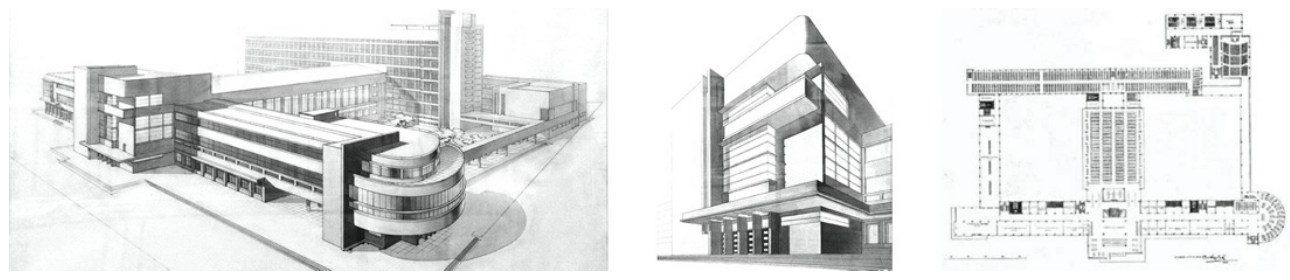

Fig. 6. A. Shchusev. Axonometric projection of Vladimir Lenin Library, 1928

The project chosen for implementation by V.Shchuko and V. Gelfreich was significantly refined during the design process and acquired the features of simplified neoclassicism, which is now commonly called postconstructivism [3, p. 524]. Interestingly, the first version of the library, made by V. Shchuko and V. Gelfreich, was completely focused on the architecture of the avant-garde [16, p. 116-117]. A clear geometricism of volumes, a combination of tape glazing and blind concrete surfaces in the complete absence of decor. The masters seemed to have missed the beginning of a new stage with its development of the classical heritage, and they had to urgently catch up. Stylized elements of the classics were introduced into the architecture (Fig. 7). The image gradually became more complex in the direction of monumentality and representativeness. Stylized elements of the classics were introduced into the architecture. It is quite obvious that the competition for the main building of the country - the Palace of Sovietsheld at the same time had a significant impact on changing the architecture of the library as a large public object of special significance (Fig. 8).

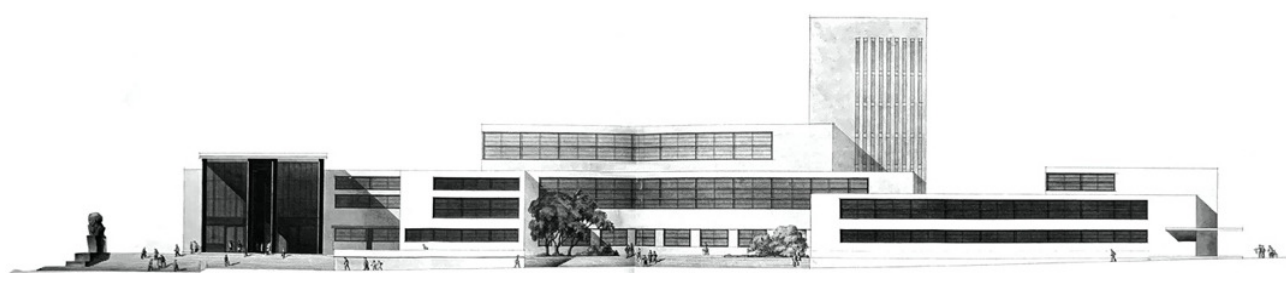

Fig. 7. V. Schuko and V. Gelfreich. The first version of the Vladimir Lenin Library, 1928

The main facade was decorated with bas-reliefs on the portico, and the long building along the highway was enriched with sculptural images designed to explain the significance of the library complex. A similar idea is pursued by the bas-relief images of scientists and thinkers placed in medallions on the lower tier of the same building. Such a method of adding additional content to the architecture of public buildings with the help of sculpture in the 1930s will 
become the norm. Famous artists were involved in the work on the sculpture of the library: V. Mukhina, M. Manizer, V. Lishev, etc.
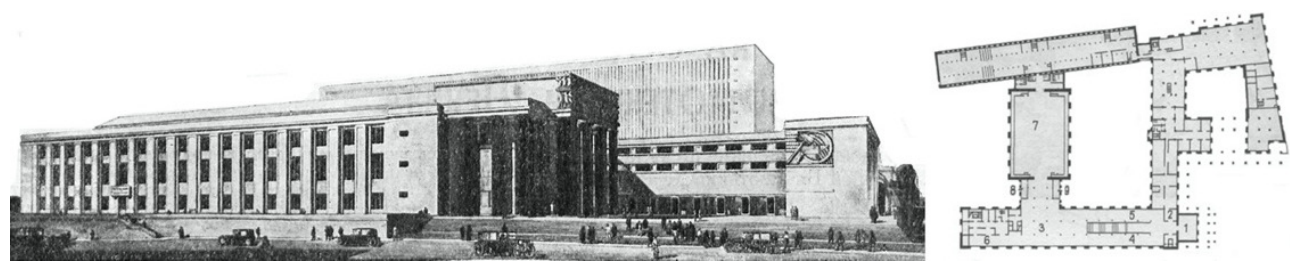

Fig. 8. V. Schuko and V. Gelfreich. The final version of the project, 1929. Perspective, plan

Particularly noteworthy is the town-planning significance of the library, which is located in the very center of the city near the Kremlin and among the historical monuments. The composition of the complex creates a beautiful perspective, closed by the building of the book depository. A significant decoration of the library is the corner terrace, framed by a colonnade, which precedes the entrance to the building. The plan of the complex is rational and clear. The buildings are interconnected and well zoned. The presence of courtyards creates a special atmosphere of silence and privacy, contributing to the introduction to intellectual pursuits.

Passing the entrance portico, which is supported by black granite columns, the visitor enters the library, where the grand staircase, striking with its palace splendor, opens before him. From the top of the stairs, you can see the perspective of the reading rooms, arranged according to the enfilade principle. The space of the halls smoothly flows into one another, creating a sense of internal unity of the compositional solution [4, p. 98]. This unity is supported by the presence of decorative details and a delicate combination of materials, which contributes to a harmonious perception of the library's interiors (Fig. 9).
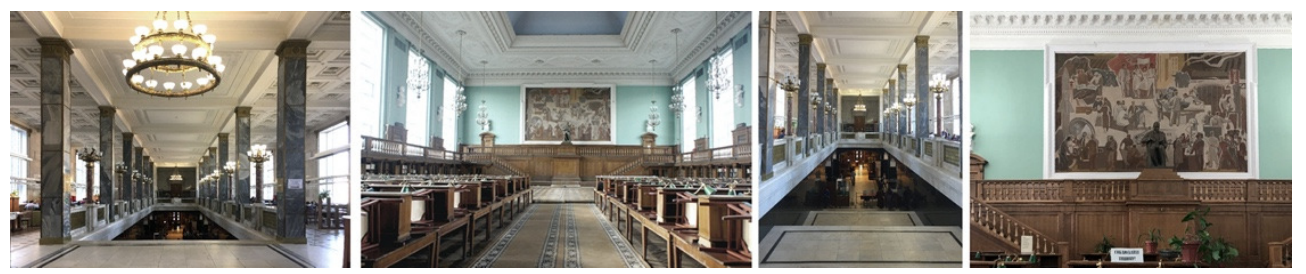

Fig. 9. Library interiors

Like other public objects of great importance, among which the library occupied one of the key places, its figurative solution and design depended on the orientation in the architecture of the 1930s. This period was characterized by the introduction of decorative elements of fairly high quality. Masters worked with facing stone, sculptural compositions, and turned to classical examples of high art to create a special high mood from the surrounding interior decoration.

\section{Conclusion}

The beginning of the creation of the image of the library was laid in VKhUTEMAS, where the students formed the initial idea of a large public building, which was to become a library, understood as the most important cultural and social center. In the process of student design, the library was transformed into a complex, filled with new functions. The competition held for the central library, which was to be located in Moscow, showed how its architectural appearance was gradually changing under the influence of changes in the architectural orientation and the competition for the Palace of Soviets.

The emphasized simplicity of the architectural forms of the 1920s was a reflection of the new way of life of post-revolutionary society, when asceticism and modesty were contrasted 
with the ostentatious luxury of the bourgeoisie. By the mid-1930s, there was a re-evaluation of values in architecture, which led to the prohibition and gradual extinction of innovative constructivist projects. The architectural community once again turned to the past, and the historical heritage became a reaction to the laconic and extremely functional architecture of the 1920s, coloring the subsequent stage of its further development with its decorative delights and admiring details.

\section{References}

[1] Chepkunova I., Kuznica bol'shoj arhitektury. Sovetskie konkursy 1920-1950-h, Katalog vystavki, Iskusstvo-XXI vek, Moscow 2014.

[2] Brat'ja Vesniny, Proekt zdanija publichnoj biblioteki sojuza SSR imeni V.I. Lenina v Moskve. Vtoroj variant/ Sovremennaja arhitektura 1929, 3, 89-94.

[3] Han-Magomedov, S.O., Arhitektura sovetskogo avangarda, V 2 kn., Kn. 2: Social'nye problemy, Strojizdat, Moscow 1996.

[4] Ikonnikov A.V., Arhitektura Moskvy XX vek, Moskovskij rabochij, 1984.

[5] Leonidov I.I.. Institut Lenina /Sovremennaja arhitektura 1928, 4-5, 120-124.

[6] Konkurs na sostavlenie proekta novogo zdanija biblioteki im. Lenina, Stroitel'stvo Moskvy 1928, 6, 3-8.

\section{Budynki bibliotek w radzieckiej architekturze lat 20. i 30.}

\section{STRESZCZENIE:}

Artykuł poświęcony jest projektowaniu i budowie bibliotek w ZSRR jako jednych z najważniejszych rodzajów budynków użyteczności publicznej, wznoszonych na przełomie lat 20. i 30. XX wieku. Omówiono trendy występujące w technikach planowania przestrzennego w zakresie rozwoju bibliotek, treści funkcjonalnych i rozwiązań architektonicznych. Przeanalizowano postępowanie konkursowe na projekt Biblioteki Lenina w Moskwie w 1928 roku i wpływ ówczesnych preferencji architektonicznych na zgłoszone projekty.

\section{SŁOWA KLUCZOWE:}

projekty konkursowe na budowę biblioteki im. W.I. Lenina; preferencje architektoniczne; specyfika projektowania bibliotek 